INTERNATIONAL BULLETIN OF BACTERIOLOGICAL NOMENCLATURE AND TAXONOMY

Volume 11, No. 4 October 15, 1961

pp. $161-164$

\title{
PROPOSAL FOR DESIGNATION OF NEOTYPE STRAINS OF LEPTOTRICHIA BUCCALIS AND \\ BACTERIONEMA MATRUCHOTII
}

To: Judicial Commission

International Committee on Bacteriological

Nomenclature of the

International Association of Microbiological Societies

Attention: Dr. R.E. Buchanan, Chairman

As noted in the accompanying reprint*, for many years there has been considerable confusion in the nomenclature of certain Gram-positive, rod-shaped or filamentous bacteria isolated from the oral cavity. As a result, two entirely different organisms have been included in the gene ra Leptothrix and Leptotrichia. To clarify this confusion the following proposal is offered.

1. Robin's name, Leptothrix buccalis Robin 1853, was invalid. (see Buchanan, Jour. Bacteriol. 3:301-306, 1918.)

2. Trevisan's proposal of the genus Leptotrichia (1879), with $\underline{L}$. buccalis Trevisan as the type species, for certain of the filamentous forms of the oral cavity was bothuseful and valid. However, he failed adequately to characterize the genus, and gave no description of the type species.

A. It must be assumed that his type species had characteristics which conformed to tho se given for the genus. (See 6A below.)

3. Trevisan's inclusion of Leptothrix buccalis Robin and Lebert as a synonym of his Leptotrichia buccalis was an error.

*Gilmour, Marion N., Arden Howell, Jr., and Basil G. Bibby. 1961. The classification of organisms termed Leptotrichia (Leptothrix) buccalis. 1. Review of the literature and proposed separation into Leptotrichia buccalis Trevisan 1879 and Bacterionema gen. nov. (Mendel 1918) comb. nov. Bacteriol. Rev. 25:131-141. 
A. The reference given was incorrect, since the name Leptothrix buccalis was first used by Robin alone in 1853.

B. Trevisan's definition of the genus Leptotrichia did not correlate with Robin's description of Leptothrix buccalis.

4. DeToni and Trevisan's later removal of Leptotrichia buccalis Trevisan to the new genus Rasmussenia as $\underline{\mathrm{R}}$. buccalis was illegitimate.

A. A new genus cannot contain the type species of a previously described genus which was legitimate.

5. De Toni and Trevisan were in error in using Leptothrix buccalis Robin and Lebert as a synonym of Rasmussenia buccalis.

A. The name Leptothrix buccalis was first used by Robin alone in 1853 , not 1847 .

B. The DeToni and Trevisan description of Rasmussenia buccalis does not correlate with that given by Robin for Leptothrix buccalis.

6. It must be assumed that DeToni and Trevisan's definition of Rasmussenia buccalis applied to Trevisan's earlier Leptotrichia buccalis for which no description was given.

A. This definition, though inadequate, correlates more closely with his earlier generic definition of Leptotrichia than does that of Robin for Leptothrix buccalis.

7. Opinion 13 of the Judicial Commission is hereby revised by the adoption of Leptotrichia buccalis Trevisan 1879 as the type species of the conserved genus Leptotrichia rather than Leptotrichia buccalis (Robin) Trevisan.

8. Culture No.14201 of the American Type Culture Collection is recognized and approved as a neotype culture of Leptotrichia buccalis Trevisan. 
B ACTERIOLOGICAL NOMENCLATURE

A. To date no other culture has been designated as a type of neotype strain. This strain conforms to the description of the venus Leptotrichia Trevisan 1879 and to some extent to that of Rasmussenia buccalis De Toni and Trevisan 1889.

B. This culture also conforms to the description of the organisms studied adequately by Thjotta et al. (1939) for which they proposed the name Leptotrichia buccalis Trevisan 1879.

9. Culture No.14266 of the American Type Culture Collection is recognized and approved as a neotype culture of Bacterionema matruchotii (Mendel, 1919), comb. nov., Gilmour, Howell, and Bibby, 1961, the type species of the new genus Bacterionema.

A. This culture correlates with the description of the organism studied and described by Kligler, 1915, as Leptothrix buccalis.

Respectfully submitted,

M.N. Gilmour, Ph.D. Research Associate, Eastman Dental Dispensary

Arden Howell, Jr., Ph. D.

Laboratory of Oral Microbiology

National Institute of Dental Research

Basil G. Bibby, B.D.S., Ph. D.

Director,

Eastman Dental Dispensary 
